US Army Corps

of Engineers

Construction Engineering

Research Laboratories

USACERL Technical Report 99/006

November 1998

\title{
Chilled Water Storage Cooling System at Fort J ackson, SC
}

by

\author{
Chang W. Sohn \\ Jerry Fuchs \\ Michael Gruber
}

For many Army installations, the electrical demand charge of their utility bills can be as high as 50 percent of the total bill. One effective way to reduce peak electrical demand and electrical utility costs is by use of storage cooling systems. To curb the anticipated growing cost of the electrical utility at Fort Jackson, the engineers at the Directorate of Public Works (DPW), Fort Jackson, decided to install a $2.25 \mathrm{M}$-gal capacity chilled water storage (CWS) cooling system for the Energy Plant No. 2, which serves more than half of the Fort's cooling load. During the first year operation (1996-1997), the system saved about $\$ 0.43 \mathrm{M}$ in electrical utility bill charges from reduced on-peak electrical demand and reduced energy consumption for cooling. This report documents the design, construction, operation, and performance of the system.

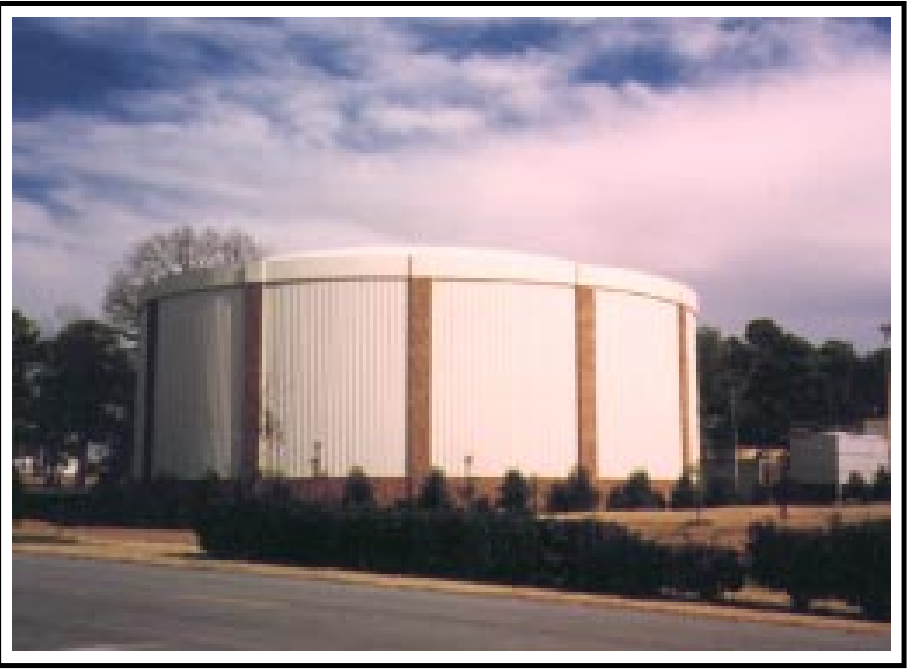




\section{SF 298}




\section{Foreword}

This study was conducted for the Directorate of Military Programs, Headquarters, U.S. Army Corps of Engineers (HQUSACE), under Project 40162784T45, "Energy and Energy Conservation"; Work Unit UL-X28, "Advanced Cooling Technologies." System operation support during the 1997 cooling season was funded by Fort J ackson through Military Interdepartmental Purchase Request (MIPR) No. 76CRL 0020, "Re-Commissioning of Chilled Water Storage Cooling System for Central Energy Plant No. 2 at Fort J ackson." The technical monitor was Tim Gordon, CEM P-ET. The Fort J ackson technical POC was J erry Fuchs, ATZJ -PWO-E.

The work was performed by the Utilities Division (UL-U) of the Utilities and Industrial Operations Laboratory (UL), U.S. Army Construction Engineering Research Laboratories (CERL). The CERL Principal Investigator was Dr. Chang W. Sohn. The designer of the system was Michael Gruber, CESAS-EN-DO. Martin J. Savoie is Chief, CECER-UL-U; J ohn T. Bandy is Operations Chief, CECER-UL; and the responsible Technical Director is Gary W. Schanche, CECER-TD. The CERL technical editor was William J. Wolfe, Technical Resources.

Dr. Michael J . O'Connor is Director of CERL. 


\section{Contents}

SF 298

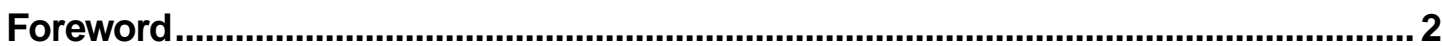

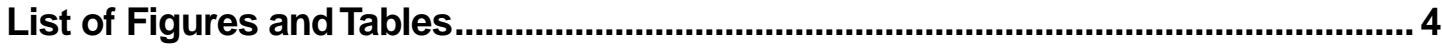

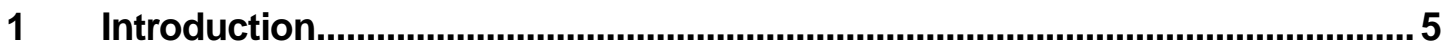

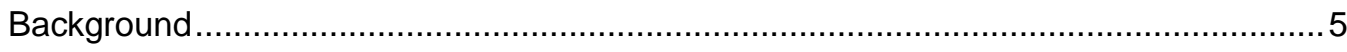

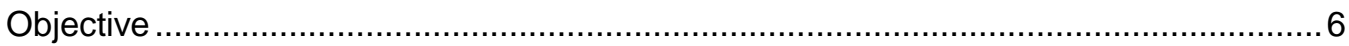

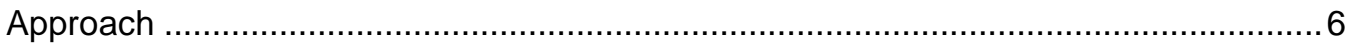

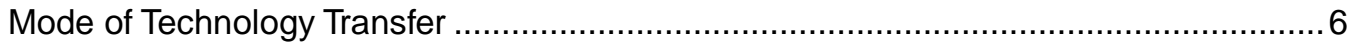

Units of Weight and Measure...............................................................................

2 System Design and Construction ............................................................. 8

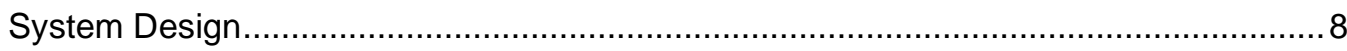

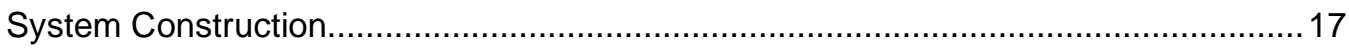

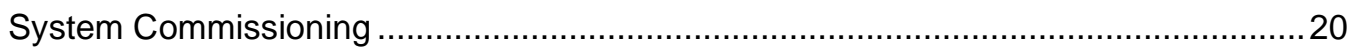

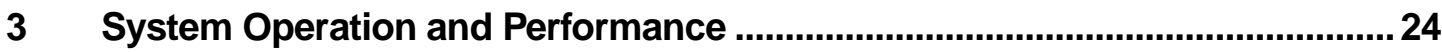

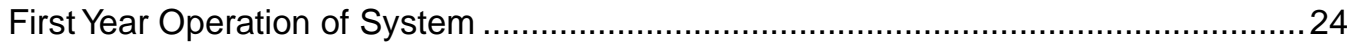

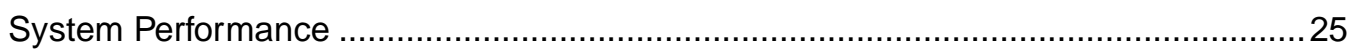

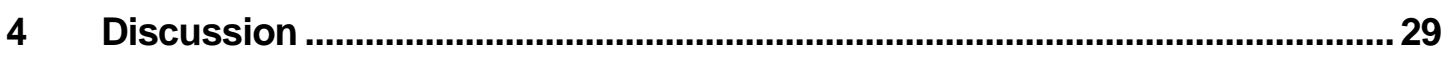

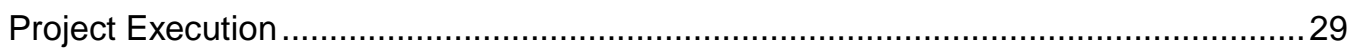

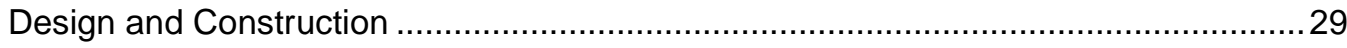

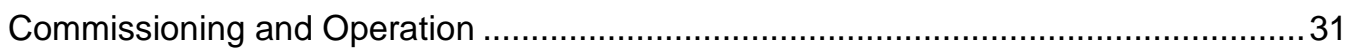

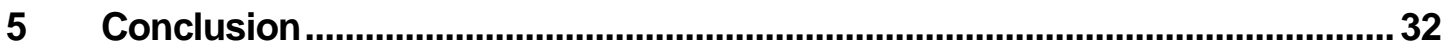

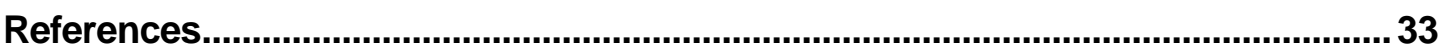

Distribution 


\section{List of Figures and Tables}

\section{Figures}

1 Hourly demand (in MW) on the peak day in 1989 (12 July 89)................................

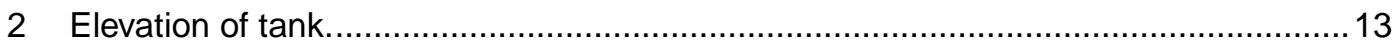

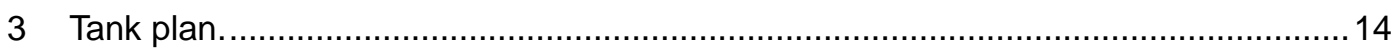

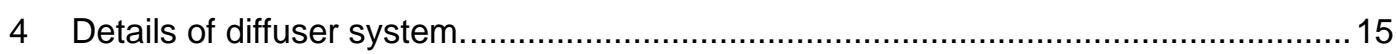

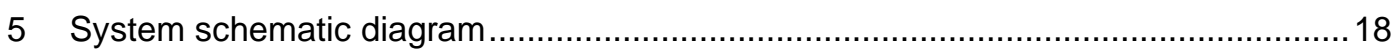

$62.25 \mathrm{M}$ gal chilled water storage tank at Fort Jackson, SC......................................... 19

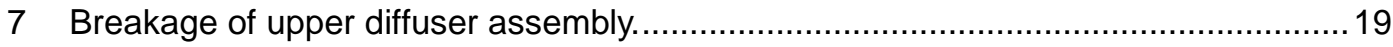

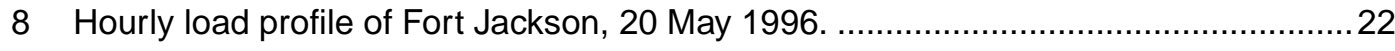

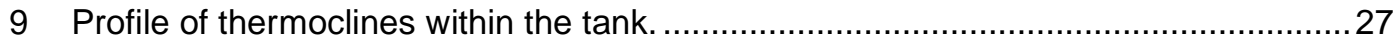

\section{Tables}

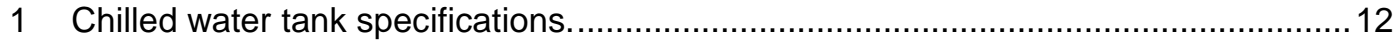

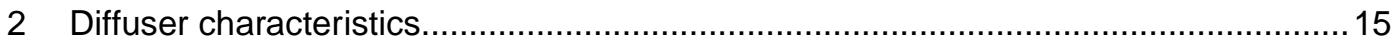

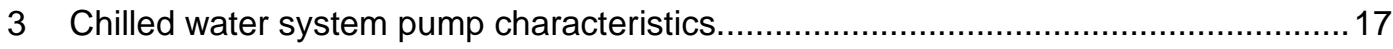

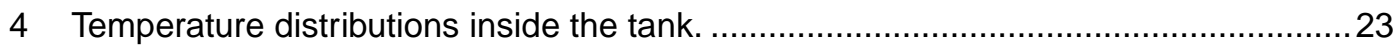

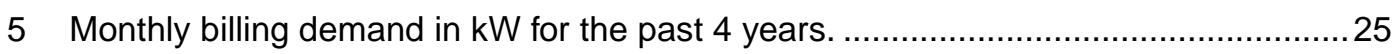

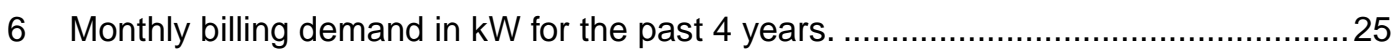

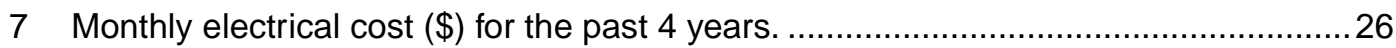

8 Annual electrical utility cost for the past 4 years.....................................................26 


\section{Introduction}

\section{Background}

In most Army installations, the electrical demand charge equals more than one third of the total electrical utility bill. For many installations, the demand portion is as high as 50 percent of the total bill (Sohn and Cler 1989). One effective way to reduce peak electrical demand and thereby to reduce electrical utility costs is through the use of storage cooling systems (Sohn 1992). Installation and use of chilled water storage systems as a way to meet cooling needs and reduce energy costs are well documented. An industry-wide design guide for storage cooling systems has been published by the American Society of Heating, Refrigerating, and Air Conditioning Engineers (ASHRAE 1993). The U.S. Army Corps of Engineers published a guide specification for military construction of storage cooling systems in 1996 (CEGS-15848; HQUSACE 1996).

A detailed analysis of end-use of electricity at Fort Hood, TX showed that cooling is responsible for 54 percent of the total peak demand of electricity (Akbari and Konopacki 1995). Fort J ackson is typical among Army installations, where summertime air conditioning accounts for a significant portion of electrical utility bills. During calendar year 1989 (CY89), the yearly electrical utility cost for Fort J ackson was $\$ 4.5 \mathrm{M}$, the demand charge was $\$ 2.2 \mathrm{M}$ (49 percent), and the energy charge was $\$ 2.3 \mathrm{M}$ (51 percent). The demand portion of the bill, as well as the total cost of the electrical utility cost, kept on growing in the following years. By CY 96 , the demand charge was $\$ 2.7 \mathrm{M}$, or 51 percent of the total electrical bill of $\$ 5.3 \mathrm{M}$.

To curb the anticipated growing cost of the electrical utility at Fort J ackson, the engineers at Directorate of Public Works (DPW), Fort J ackson, decided in early 1990 to install a chilled water storage (CWS) cooling system for the Energy Plant No. 2, which serves more than half of the Fort's cooling load. The U.S. Army Corps of Engineers Construction Engineering Research Laboratories (CERL) conducted a feasibility study in 1990. The results showed a simple payback of a CWS cooling system less than 5 years (Sohn 1990). Based on the results of the study, the Army Energy Conservation Investment Program (ECIP) funded the project in fiscal year 1993 (FY93). The South Carolina Electric and Gas 
Company offered an incentive program for the thermal storage at Fort J ackson at a rate of $\$ 300 / \mathrm{kW}$ deferred (Memorandum of Understanding [MOU] 1995). The one-time incentive award shortened the system payback time to less than the time predicted in the earlier feasibility study.

\section{Objective}

The objectives of this study were: (1) to document the design, construction, and operational performance of a CWS cooling system at Fort J ackson, SC, (2) to provide a design, construction, and operation reference on CWS cooling systems for Army engineers, and as a result, (3) to assist Fort J ackson DPW engineers to further improve system operation.

\section{Approach}

A description of the project was made from the design and construction of the system to the operation and performance analysis up to the second year of operation. The system's economic performance was analyzed using monthly electrical utility bills from 1994 through 1997. The system energy performance was measured by the on-site instrumentation with the EMCS system at Fort $\mathrm{J}$ ackson. Actual system payback period was calculated by the total project cost spent and the annual savings in the electrical utility cost as reflected in the monthly electrical bills during the first year of system operation.

\section{Mode of Technology Transfer}

A summary of this work was presented to the U.S. Army Corps of Engineers 1998 Electrical and Mechanical Engineering Training Conference (Sohn, Fuchs, and Gruber 1998). It is also recommended that the information in this report be incorporated into the Corps of Engineers guide specification on chilled water storage cooling systems. For the U.S. Army installation engineers, this report can serve as a reference for project development and implementation of chilled water storage cooling systems. 


\section{Units of Weight and Measure}

U.S. standard units of measure are used throughout this report. A table of conversion factors for Standard International (SI) units is provided below.

\begin{tabular}{|rl|}
\hline SI Conversion Factors \\
\hline $1 \mathrm{in.}$ & $=25.4 \mathrm{~mm}$ \\
$1 \mathrm{ft}$ & $=0.305 \mathrm{~m}$ \\
$1 \mathrm{yd}$ & $=0.9144 \mathrm{~m}$ \\
$1 \mathrm{sq} \mathrm{in.}$ & $=6.452 \mathrm{~cm}^{2}$ \\
$1 \mathrm{sq} \mathrm{ft}$ & $=0.093 \mathrm{~m}^{2}$ \\
$1 \mathrm{sq} \mathrm{yd}$ & $=0.836 \mathrm{~m}^{2}$ \\
$1 \mathrm{cu} \mathrm{in.}$ & $=16.39 \mathrm{~cm}^{3}$ \\
$1 \mathrm{cu} \mathrm{ft}$ & $=0.028 \mathrm{~m}^{3}$ \\
$1 \mathrm{cu} \mathrm{yd}$ & $=0.764 \mathrm{~m}^{3}$ \\
$1 \mathrm{gal}$ & $=3.78 \mathrm{~L}$ \\
$1 \mathrm{lb}$ & $=0.453 \mathrm{~kg}$ \\
$1 \mathrm{kip}$ & $=453 \mathrm{~kg}$ \\
$1 \mathrm{psi}$ & $=6.89 \mathrm{kPa}$ \\
${ }^{\circ} \mathrm{F}$ & $=\left({ }^{\circ} \mathrm{C} \times 1.8\right)+32$ \\
$1 \mathrm{ton}(\mathrm{cooling})$ & $=12,000 \mathrm{BTU} / \mathrm{hr}$
\end{tabular}




\section{System Design and Construction}

\section{System Design}

The system was designed by the U.S. Army Corps of Engineers Savannah District Office (CESAS) during FY93 in cooperation with DPW Fort J ackson and CERL.

\section{Design Goal}

The design goal of the chilled water storage (CWS) system for the Central Energy Plant (CEP) No. 2 at Fort J ackson was to shift operation of the four 120ton chillers, from the summer on-peak hours (1300-2100, Monday-Friday excluding holidays) to off-peak hours. Recall that Fort J ackson has a master meter for measuring the installation-wide electrical demand for billing purposes. Figure 1 shows the hourly demand profile for the peak day in 1989.

Based on the new chiller rating of $0.64 \mathrm{~kW} /$ ton, turning off the four chillers (1200 ton each) at CEP No. 2 would reduce the electrical demand (P) by:

$$
\mathrm{P}=4^{*} 1200(\text { ton })^{*} 0.64(\mathrm{~kW} / \text { ton })=3072(\mathrm{~kW})
$$

According to the hourly demand profile shown in Figure 1, reduction of $3000 \mathrm{~kW}$ in demand could be achieved by turning off the four chillers from 1300-1800 hours. Therefore, the goal of the system design was to shift the electrical demand of $3000 \mathrm{~kW}$ from on-peak to off-peak periods.

\section{Central Energy Plant No. 2 Operating Conditions}

CEP No. 2 has four chillers, each rated at a 1200-ton capacity. CEP No. 2 serves more than half of the major buildings at Fort J ackson. Main supply lines branch from the plant in two zones. The total flow rate for CEP No. 2 is $8300 \mathrm{gal} /$ minute (gpm) for the two zones, Zone 1 and Zone 2. The normal differential temperature of the chilled water is $12^{\circ} \mathrm{F}$ with supply water temperature of $42{ }^{\circ} \mathrm{F}$, and return water temperature of $54^{\circ} \mathrm{F}$. At night, the plant has a minimum of 2000 ton of cooling capacity to charge the tank. 


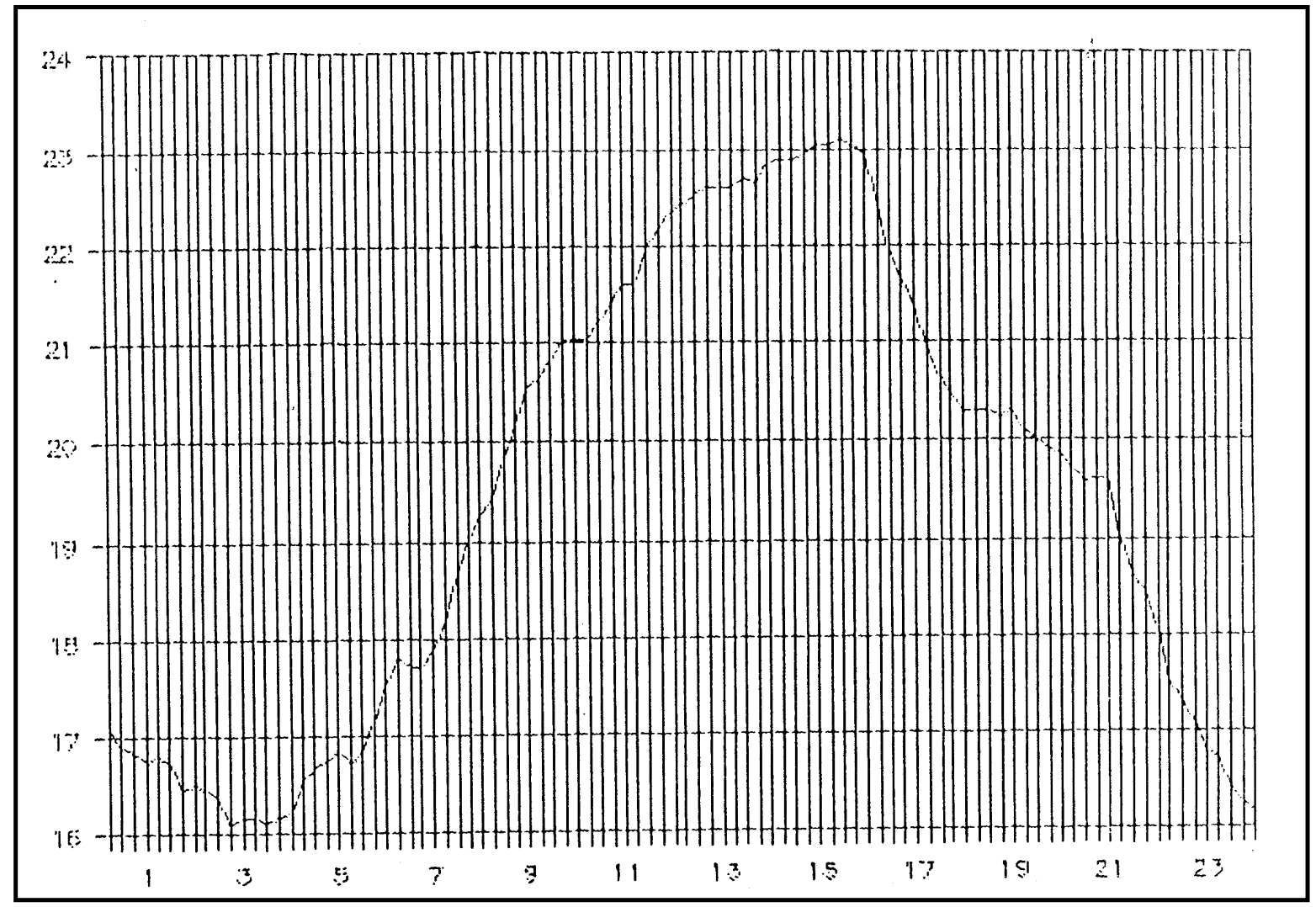

Figure 1. Hourly demand (in MW) on the peak day in 1989 (12 July 89).

Recall that CEP No. 2 serves more than half of the major buildings at Fort $\mathrm{J}$ ackson, which requires cooling round the clock.

\section{Tank Sizing}

The storage capacity of the tank should be large enough to store enough cooling to meet the cooling demands of CEP No. 2 for a selected period of a day. Based on the operational data from CEP No. 2, the integrated cooling load from 1300 to 1800 hours was estimated to be 16,000 ton-hr. With a 5 percent safety factor, the design cooling capacity $(\mathrm{Q})$ of the storage tank was determined to be:

$$
\mathrm{Q}=16,800 \text { ton-hr }
$$

The storage volume (V) of the tank is determined by the cooling capacity (Q), differential temperature between the supply and the return water (dT), and the figure-of-merit (FOM) of the storage tank. For a storage tank with well designed diffuser system, the FOM is recommended to be 0.9. (ASHRAE 1993). The 
temperature differential for CEP No. 2 is $12{ }^{\circ} \mathrm{F}$. Based on the these data, the volume of the storage tank was determined by:

$$
\begin{aligned}
V & =\mathrm{Q} /\left[\mathrm{C}_{\mathrm{p}}{ }^{*} \mathrm{dT}{ }^{*} \mathrm{FOM}\right] \\
& =16800(\text { ton-hr }){ }^{*} 12000(\mathrm{Btu} / \mathrm{ton}-\mathrm{hr}) /\left[1\left(\mathrm{Btu} / \mathrm{lbm}{ }^{\circ} \mathrm{F}\right) * 12\left({ }^{\circ} \mathrm{F}\right){ }^{*} 0.9 * 8.36(\mathrm{lbm} / \mathrm{gal})\right] \\
& =2.232 \mathrm{M} \text { (gal) }
\end{aligned}
$$

The volume of the storage tank was determined to be $2.25 \mathrm{M}$ gal.

\section{Tank and Diffuser Design}

Due to the multiple competing options in the market (such as concrete or steel tank, and linear or radial diffuser), the CESAS bid specifications prescribed the functional requirements for the tank. The functional requirements included the storage volume, the storage cooling capacity, and the design of diffuser system as well as the other requirements such as aesthetic requirements from Fort J ackson. A particular aesthetic requirement was the height of the tank, which was not to exceed that of the nearby facility. The maximum height of the water column in the tank was limited to $40 \mathrm{ft}$. The bidders were requested to provide the details of the design of their choices, and the designs were subjected to the approval from the design team of the Savannah District Office, Fort J ackson, and CERL. The important characteristics of the approved design follow.

Tank Configuration. Tanks with low surface-to-volume ratios have a lower degree of thermal loss and have a lower cost per ton-hour of stored cooling construction cost. Therefore, flat-bottomed vertical cylinders are favored. Concrete tanks with height-to-diameter ratios between 0.25 and 0.33 represent a good compromise between a low-cost short tank and a tall tank that provides the best thermal stratification (ASHRAE 1993). Other factors must also be considered when determining tank dimensions, such as required flow rates and dimensions of the diffuser, and site conditions. The allowable bearing capacity of the soil as well as special architectural concerns should be taken into consideration. One particular criterion for the tank design at Fort J ackson was that the height of the tank not exceed the height of the tallest structure in its vicinity. A 40-ft tank water level, with a maximum tank height at $44 \mathrm{ft}$, was chosen. The resulting diameter was calculated as:

$$
\begin{aligned}
\mathrm{H} & =40 \mathrm{ft} \\
\mathrm{D} & =2^{*}(\mathrm{~V} / \pi \mathrm{H})^{(1 / 2)} \\
& =2^{*}((2,25 \mathrm{M} \mathrm{gal}) /(7.48 \mathrm{gal} / \mathrm{cu} \mathrm{ft})(\pi)(40 \mathrm{ft}))^{1 / 2}=98 \mathrm{ft}
\end{aligned}
$$


An aboveground cylindrical concrete tank was chosen with a 40-ft water level and 98 -ft diameter. The resulting tank height-to-diameter ratio was 0.41 , which favors thermal stratification in the tank. The tank was built on a reinforced concrete ring wall. A reinforcing steel rod skeleton was constructed and an encased inner steel shell was attached to the skeleton. Shotcrete was applied and allowed to cure and insulation was added to the walls. A synthetic stuccocovered exterior was added to the exterior of the tank for aesthetic reasons. Table 1 summarizes tank design characteristics. Figure 2 shows a diagram of the tank, including its elevation. Figure 3 shows the Tank Plan. An earlier paper reported to the 1995 USACE Electrical and Mechanical Engineering Training Conference (Burch 1995) discusses the tank's design in detail.

Internal Diffuser Design. A chilled water storage tank needs diffusers to introduce water into the tank without creating disturbances in the fluid that could result in the deterioration of the thermocline. During charging the tank, a gravity current of cool, dense water is produced by the lower diffuser near the tank floor, and is spread horizontally. Similarly, a gravity current of less dense warm water is produced near the top of the tank by the upper diffuser during discharge. Octagonal diffusers, formed from eight straight sections of pipe connected with 135-degree elbows, have proved successful in the past for creation and maintenance of the thermodine in the tank. Octagonal diffusers with both the lower and upper array consisting of four rings were chosen to ensure proper stratification. The upper and lower diffusers were identical in shape. A maximum of 20 psid pressure loss from inlet flange to outlet flange was specified, as well as design flow rates of $4,000 \mathrm{gpm}$ (charging) and 8,000 gpm (discharging). Due to the competing technologies and builders in the market, the CESAS design left the actual design of the internal diffuser to the contractor to be selected through an open bidding. However, the performance of the diffuser was prescribed to meet the industry recommendation of the maximum inlet Reynolds Number to be less than 2000, and the Froude number less than 2 (ASHRAE 1993). The final design of the diffuser by the successful bidder was a quadruple octagonal diffuser system with the total linear diffuser length of $851 \mathrm{ft}$ (Figure 4). Note that Figure 4 is intended to convey the general configuration of the diffuser system, not the fine details of each segment. 
Table 1. Chilled water tank specifications.

\begin{tabular}{|l|l|}
\hline Cooling capacity & 16,800 ton-hour \\
\hline Size & $2.25 \mathrm{M} \mathrm{gal}$ \\
\hline Mean diameter & $98 \mathrm{ft}$ \\
\hline Water level height & $40 \mathrm{ft}$ \\
\hline Height-to-diameter ratio & 0.41 \\
\hline Plan area & $7,543 \mathrm{sq} \mathrm{ft}$ \\
\hline $\begin{array}{l}\text { Vertical core wall } \\
\text { thickness }\end{array}$ & $\begin{array}{l}\text { Tapers from } 71 / 4 \text { in. at bottom to } 31 / 2 \text { in. at top including } 1 \text { in. cover over } \\
\text { steel shell diaphragm. }\end{array}$ \\
\hline Vertical wall material & $\begin{array}{l}\text { Prestressed composite wall (steel shell/shotcrete) with } 5 \text { in. thick rigid } \\
\text { Styrofoam insulation glued to concrete tank and finished vee rib outer } \\
\text { sheeting; brick outer shell for bottom 7 ft-8 in. }\end{array}$ \\
\hline Dome shell & 3-in. thick concrete with expanded polystyrene insulation \\
\hline Floor & 5-in. concrete with painted outer surface \\
\hline
\end{tabular}

Table 2 lists detailed characteristics of the installed diffuser system.

An underground 24-in. chilled water supply pipe and 24-in. chilled water return pipe connected the storage tank to CEP No. 2. The flow branched into two separate 20-in. PVC pipes and was carried to the first octagonal ring. All octagonal ring diffusers were 14-in. PVC. Total diffuser length, which represented the sum of the four octagonal rings, was $851.0 \mathrm{ft}$. The sections of pipe had slots cut into them, through which the flow was diffused into the tank. The area of each slot was set such that the sum of the slot areas in each diffuser pipe equaled the cross-sectional diffuser pipe area. The calculation of an effective diffuser length based on twice the total diffuser length was necessary to account for the fact that the water is diffused into the tank in both the radial inward and radial outward directions. Total flow rate was based on 125 percent of the design discharge rate and was cal culated as:

$(8,000 \mathrm{gpm})(1.25) /(60 \mathrm{sec} / \mathrm{min})(7.48 \mathrm{gal} / \mathrm{cu} \mathrm{ft}))=22.3 \mathrm{cu} \mathrm{ft} / \mathrm{sec}$

Since the diffuser design included 32 sections of pipe, each diffuser pipe flow rate was calculated to be:

$(22.3 \mathrm{cu} \mathrm{ft} / \mathrm{sec}) / 32=0.7 \mathrm{cu} \mathrm{ft} / \mathrm{sec}$

Mixing in the tank is also influenced by the inlet flow rate per unit length of diffuser, expressed by the Reynolds number. A maximum Reynolds number of 2,000 was specified for the design of the diffuser. The Reynolds number is defined as the flow rate per foot of diffuser length divided by the kinematic viscosity of inlet water. The total diffusion rate was:

$22.3 \mathrm{cu} \mathrm{ft} / \mathrm{sec} / 1,702 \mathrm{ft}=0.01310 \mathrm{sq} \mathrm{ft} / \mathrm{s}$ 


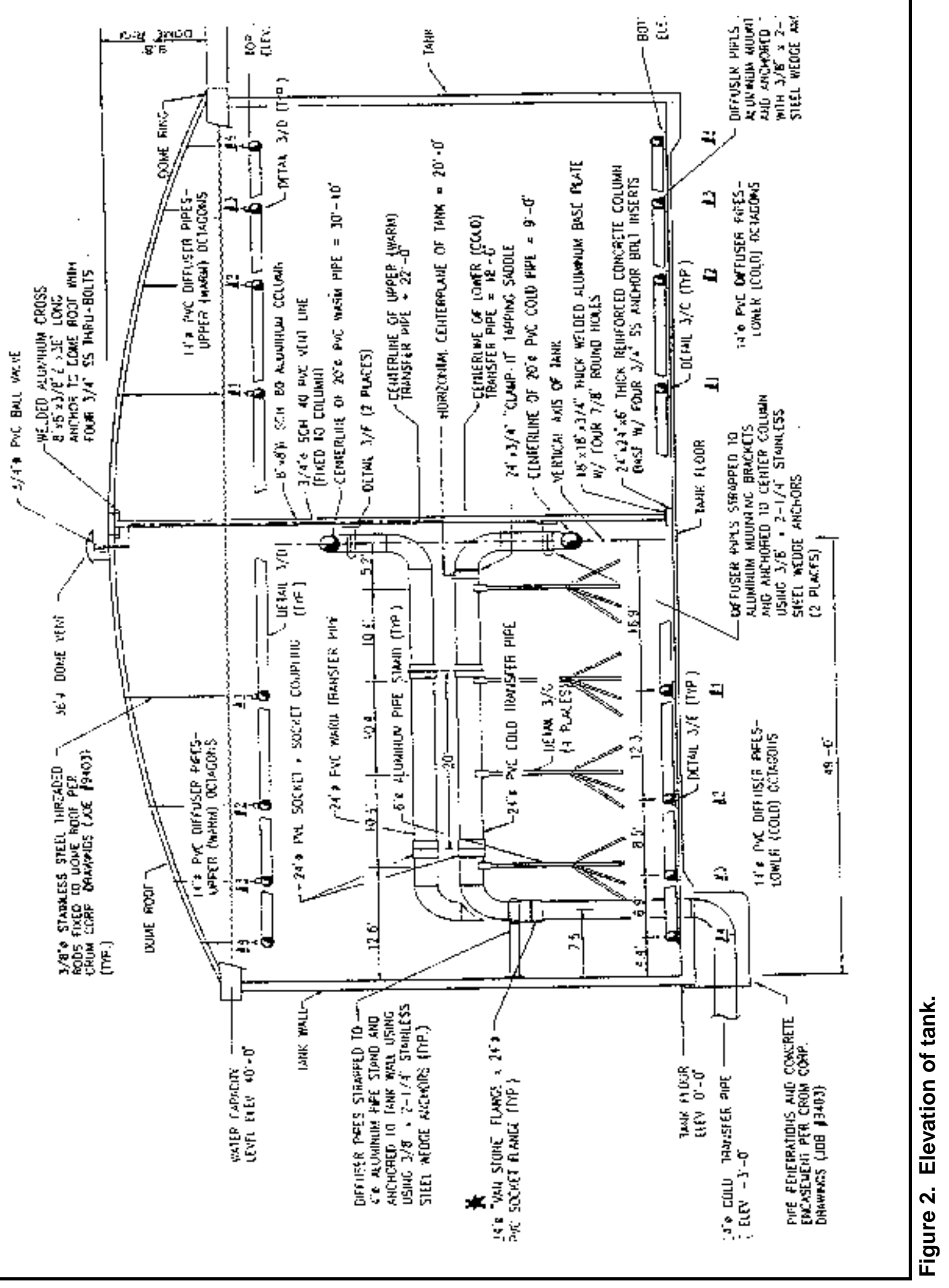




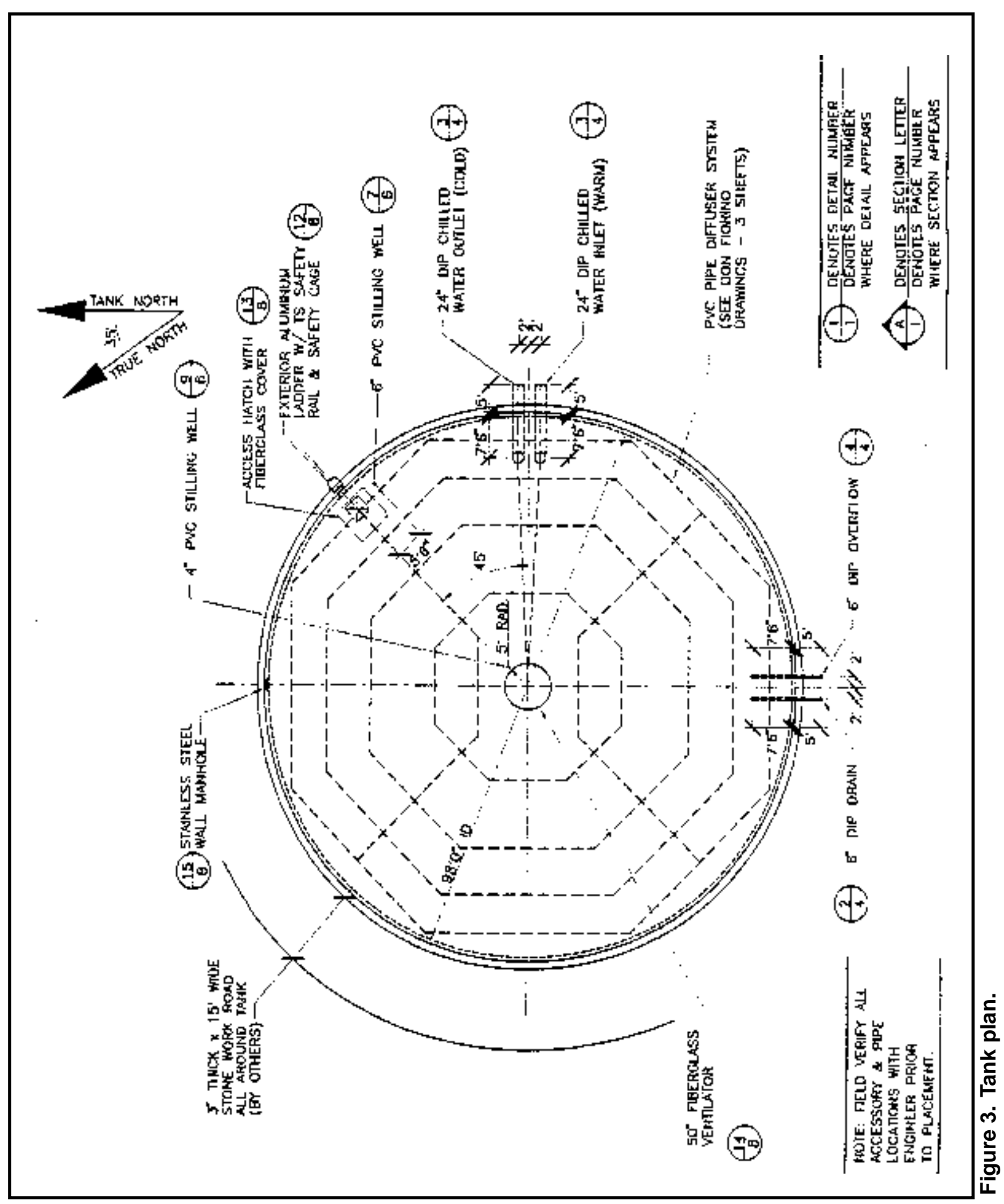




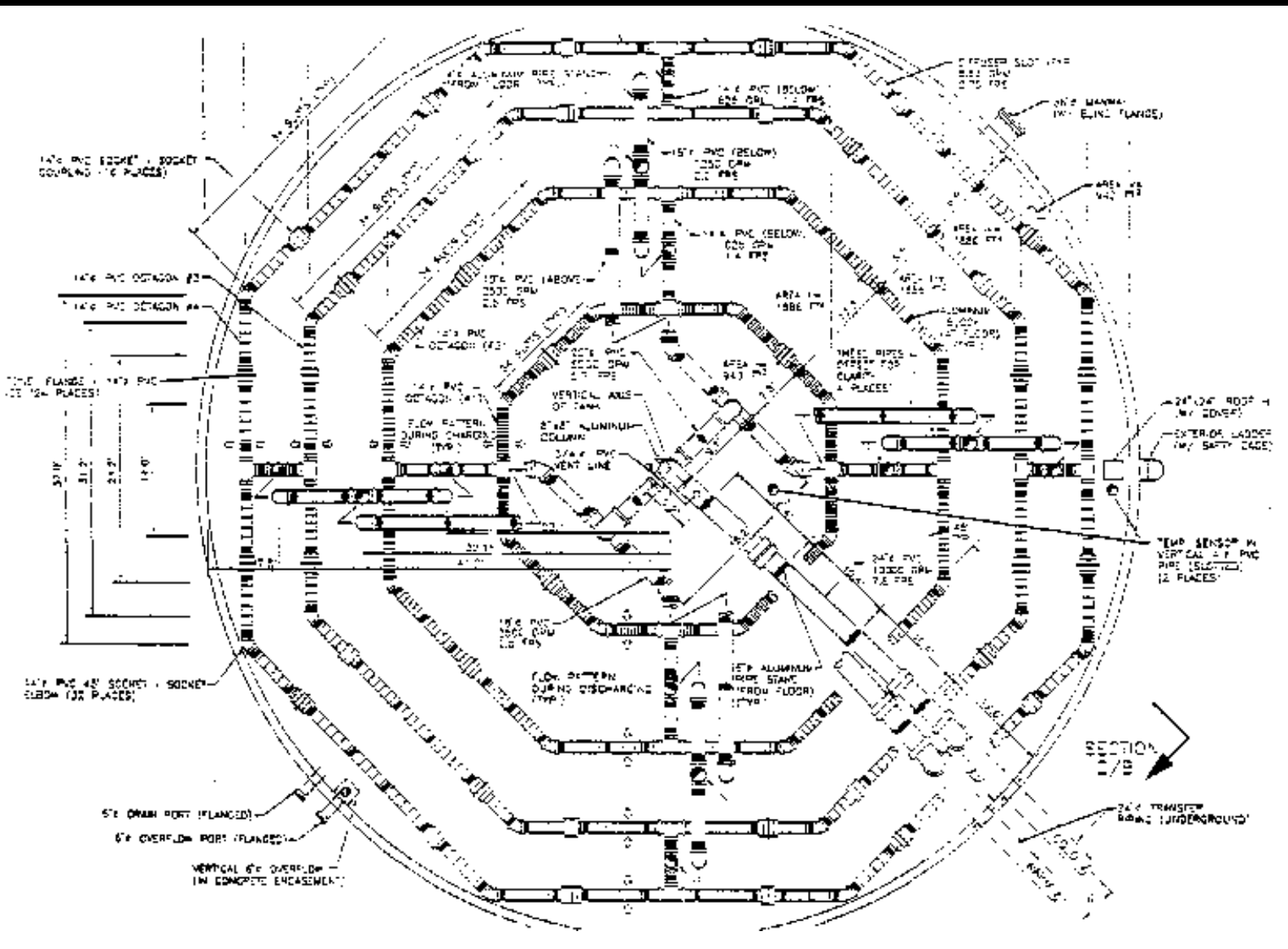

Figure 4. Details of diffuser system.

Table 2. Diffuser characteristics.

\begin{tabular}{|l|l|}
\hline Design inlet temperature during discharge cycle & $54^{\circ} \mathrm{F}$ \\
\hline Design outlet temperature during discharge cycle & $42^{\circ} \mathrm{F}$ \\
\hline Design inlet temperature during charge cycle & $41^{\circ} \mathrm{F}$ \\
\hline Reynolds number & $811(2,000$ design) \\
\hline Design Froude number & 0.5 \\
\hline Each diffuser pipe flow rate & $0.7 \mathrm{cu} \mathrm{ft} / \mathrm{sec}$ \\
\hline Number of slots in each diffuser pipe & 34 \\
\hline Flow rate of each slot & $0.0206 \mathrm{cu} \mathrm{ft} / \mathrm{sec}$ \\
\hline Cross-sectional diffuser area & $1.0 \mathrm{sq} \mathrm{ft}$ \\
\hline Slot area & $0.0294 \mathrm{sq} \mathrm{ft}$ \\
\hline Slot inlet/exit velocity & $0.70 \mathrm{ft} / \mathrm{sec}$ \\
\hline Slot width & $3 / 8 \mathrm{in}$. \\
\hline Slot length & $11.4 \mathrm{in}$. \\
\hline Length of each diffuser pipe in octagon \#1 & $14.0 \mathrm{ft}$ \\
\hline Length of each diffuser pipe in octagon \#2 & $24.2 \mathrm{ft}$ \\
\hline Length of each diffuser pipe in octagon \#3 & $31.2 \mathrm{ft}$ \\
\hline Length of each diffuser pipe in octagon \#4 & $37.0 \mathrm{ft}$ \\
\hline
\end{tabular}


The Reynolds number was calculated as:

$$
\operatorname{Re}=(0.01310 \mathrm{sq} \mathrm{ft} / \mathrm{sec}) /(0.00001615 \mathrm{sq} \mathrm{ft} / \mathrm{sec})=811
$$

This Reynolds number value was less than the design maximum allowable (2000) recommended in the industry standard design guide (ASHRAE 1993).

The Froude number is defined as the dimensionless ratio of the inertia force to the buoyancy force acting on a fluid. Gravity currents, which are necessary for the proper performance of the tank, will form for Froude numbers less than 1 with limited mixing. The Froude number criterion is used to determine the required inlet height of the diffuser. For a diffuser close to the bottom of the tank, the inlet height is defined as the distance from the tank floor to the top of the diffuser inlet opening. For a chilled water tank, the Froude number is defined as:

$$
F r_{i}=q /\left[g h^{3}\left(\rho_{i}-\rho_{a}\right) / \rho_{a}\right]^{1 / 2}
$$

Eq. 1

where:

$$
\begin{aligned}
& q=\text { volume flow rate per unit diffuser length } \\
& g=\text { acceleration of gravity } \\
& h=\text { minimum inlet opening height } \\
& \rho_{1}=\text { density of inlet water } \\
& \rho_{a}=\text { density of ambient water }
\end{aligned}
$$

and

$$
q=Q / L
$$

Eq. 2

where:

$$
\begin{aligned}
& Q=\text { maximum flow rate } \\
& L=\text { effective diffuser length. }
\end{aligned}
$$

A Froude number of 0.5 was selected for design of the inlet opening height. Other values necessary for the calculation included:

$$
\begin{aligned}
& q=0.01310 \mathrm{sq} \mathrm{ft} / \mathrm{sec} \\
& \mathrm{g}=32.17 \mathrm{ft} / \mathrm{sec}^{2} \\
& \rho_{\mathrm{i}}=\text { density of inlet water } \\
& \rho_{\mathrm{a}}=\text { density of ambient water. }
\end{aligned}
$$


Solving for the inlet height yielded a value of $0.35 \mathrm{ft}$ (which, in the final design, was set at $4 \mathrm{in}$.). The bottom of the lower diffusers were placed $2 \mathrm{in}$. above the tank floor. The top of the upper diffusers were placed $4 \mathrm{in}$. from the free surface in the original design.

\section{System Schematics}

Four primary chilled water pumps (PCWP) serve the chillers. Two regenerative turbine pumps (RTP) serve the chilled water tank and one heat exchanger pump (HEP) serves the heat exchanger for free cooling application. Also included are four system chilled water pumps (SCHP). Each of the pumps has the characteristics described in Table 3. Two-way, two-position, normally open electric solenoid actuated pneumatic valves are located at each of the four PCHPs. Temperature sensors were mounted inside the storage tank to measure the vertical temperature profile and thermocline thickness in the tank. Figure 5 shows a schematic of the chilled water storage system.

\section{System Construction}

Construction of the system was accomplished in two phases. In the phase 1, the tank with internal diffuser system was built in 1994 (Figure 6). Figures 2 ( $p$ 13) and 3 ( $p$ 14) show the plan and elevation of the tank with the internal diffuser system installed inside the tank. Figure 4 shows the layout of the diffuser segments. Note that the top and the bottom diffusers are a mirror image.

Phase 2 consisted of adjusting the piping inside the energy plant (CEP No. 2) and the pipe connection from the storage tank to CEP No. 2 during the offcooling season of 1995-96. The phase 2 work was completed in March 1996. During the commissioning of the tank to the cooling loop of CEP No. 2, a major breakage of the upper diffuser assembly inside the tank was detected. Figure 7 shows a typical breakage of the diffuser. The tank was drained, the cause of failure was investigated, and the upper diffuser assembly was repaired for a successful system commissioning on 20 May 1996.

Table 3. Chilled water system pump characteristics.

\begin{tabular}{|l|r|r|r|r|}
\hline & \multicolumn{1}{|c|}{ RTP } & \multicolumn{1}{|c|}{ PCHP } & \multicolumn{1}{|c|}{ SCHP } & \multicolumn{1}{|c|}{ HEP } \\
\hline GPM & 2,000 & 2,060 & 2,600 & 2,000 \\
\hline Total head (feet) & 70 & 25 & 175 & 35 \\
\hline Max horsepower & 80 & 20 & 150 & 20 \\
\hline RPM & 1,750 & 1,170 & 1,750 & 1,170 \\
\hline
\end{tabular}




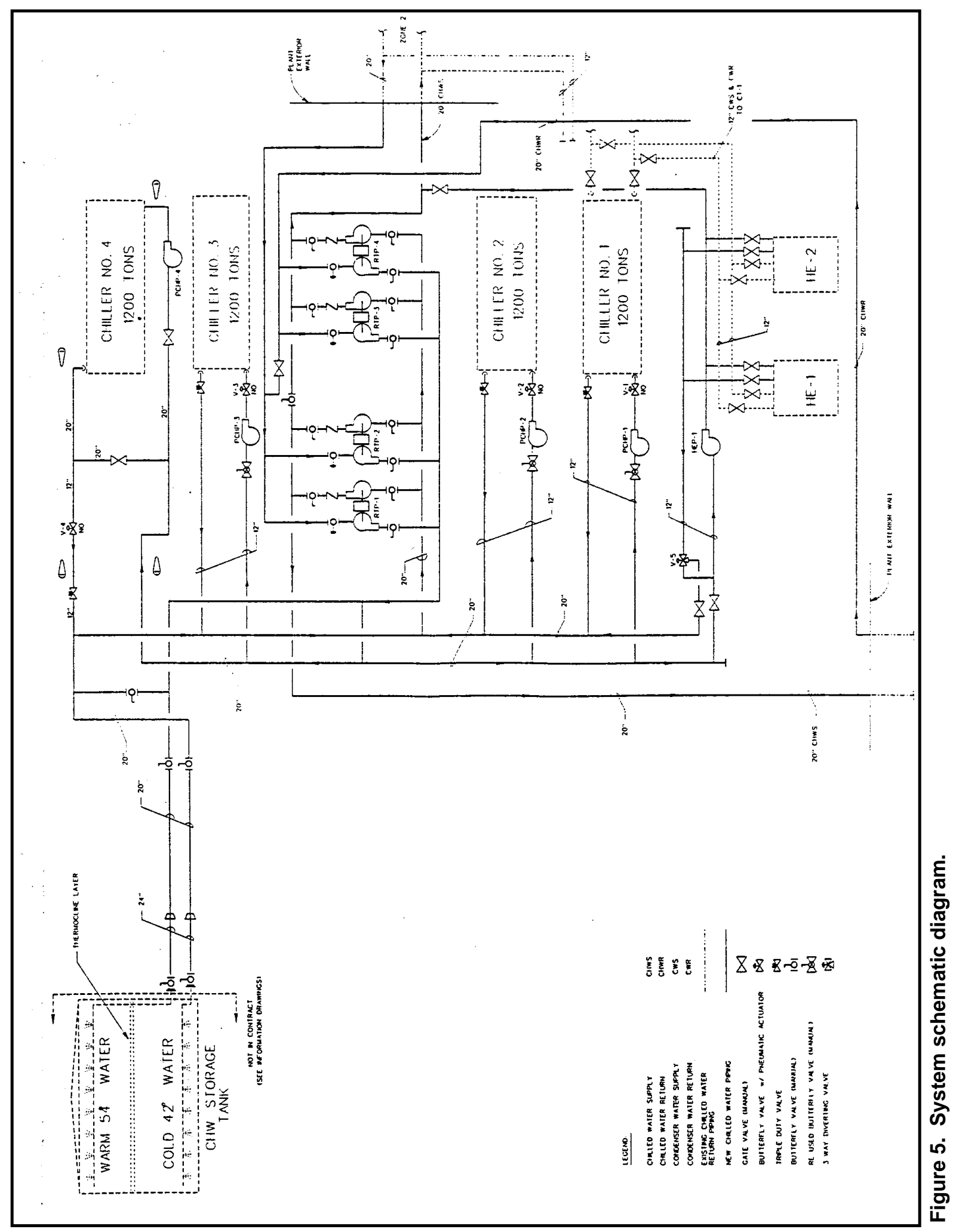




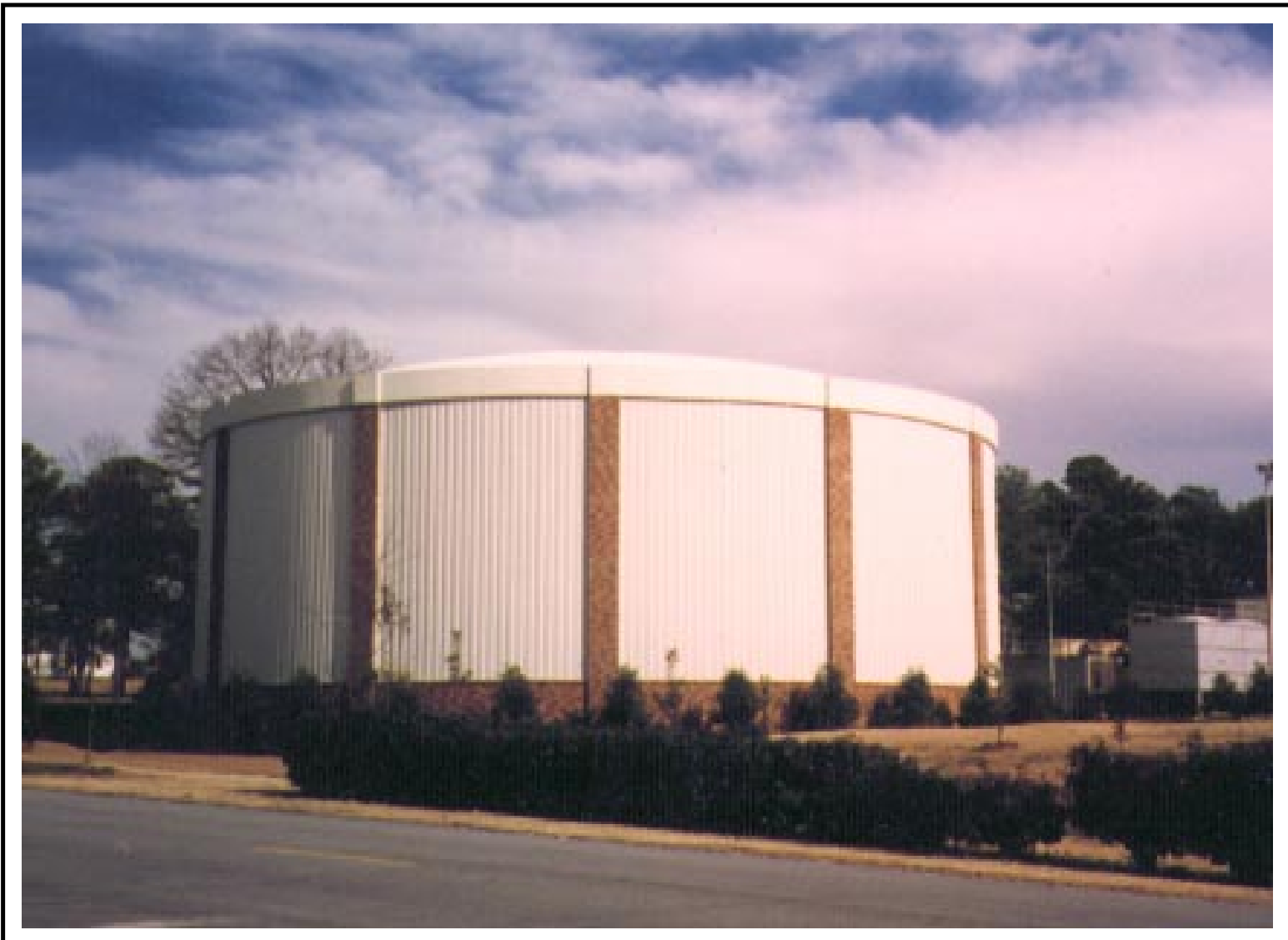

Figure 6. 2.25M gal chilled water storage tank at Fort Jackson, SC.

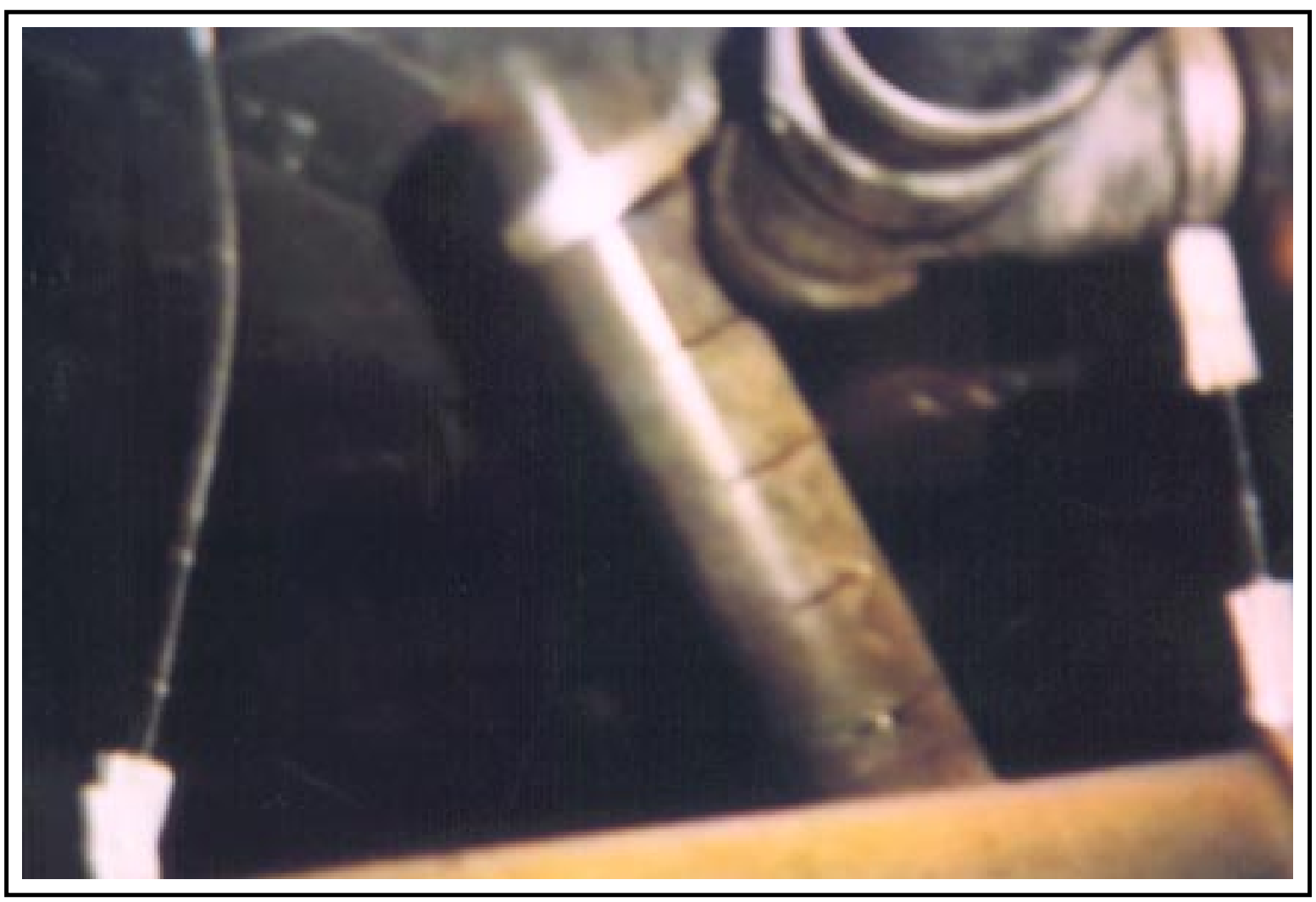

Figure 7. Breakage of upper diffuser assembly. 


\section{System Commissioning}

\section{Breakage and Repair of Upper Diffuser Assembly}

Note that the upper distribution diffuser system (shown in Figure 2, "Elevation of Tank") is hanging from the ceiling with 3/8-in. stainless steel threaded rods fixed to the dome roof. About 26 breakage points in the upper diffuser system, including diffuser and riser (feeder line to diffuser), were noticed (see Figure 7). The postulated causes of failure and repairs made are:

1. Buoyancy on the diffuser due to air pocket. When the tank was initially filled with water, the tank was not connected to CEP No. 2. Water was introduced through the opening at the ceiling. The two 24-ft main transfer lines (to and from the tank, shown in Figure 2) remained closed by isolation valves. Water was introduced into the diffuser assembly through the slots into the closed pipe space. The lower diffuser assembly is anchored to the concrete floor with aluminum mounting pads between the diffuser and floor. The pad and anchor holds the lower diffuser assembly securely against any potential buoyancy forces. On the other hand, the upper diffuser is secured by the 3/8-in. rods, which cannot provide resistance to compression induced by potential buoyancy force due to air pocket inside the upper diffuser assembly. The solution was to install a bypass line across the two 24-in. main transfer lines. A short 11-in. piping with a shutoff valve in the middle was installed between the two main transfer lines just outside the tank. When filling the tank, the bypass line will equalize the rising water level between the inside and outside of the diffuser system, thereby eliminating any potential buoyancy effects.

2. Valve actuating speed. Line-sized butterfly control valves are installed at the outlet of recovery turbines in CEP No. 2. The opening speed of these valves was so fast that it could induce water hammer effects al ong the line, including the diffusers inside the tank. The solution was to slow the valve opening and closing speed to 60 seconds for full opening and dosing the valves.

3. Loose connection of main transfer line to upper diffuser. The flange bolts connecting the 24-in. steel main transfer line from CEP No. 2 to the 24-in. PVC line to the upper diffuser assembly (marked with an asterisk [*] in Figure 2) within the tank were missing nuts underneath the flange. The loose connection would have generated a significant flow-induced vibration of the upper diffuser structure when a full charge flowrate was introduced to the tank. The flange nuts were installed and tightened for a secure connection of the 24-in. main transfer line for the upper diffuser.

4. Leveling of Upper Diffuser. The broken parts of upper diffuser were fixed and the tank was fully charged with city water. One major concern was the levelness of 
upper diffuser segments. A DPW engineer entered the tank and measured the elevation of high spots along the diffuser segments. The maximum elevation differential at the highest spot was measured to be 5 in. The original design water depth between the top surface of water and the highest point in the diffuser was $8 \mathrm{in}$. With the unevenness of up to 5 in., the operating water depth would be reduced down to 3 -in. at the highest spot. In case of potential rapid loss of water in the system, e.g., a rupture in the distribution line, the 3-in. margin was deemed too shallow to prevent potential exposure of diffuser slots to atmosphere. Exposure of slots to open air will result in the introduction of air into the circulation system. The solution was to raise the operating tank water level by $7 \mathrm{in}$. by extending the overflow level from $40 \mathrm{ft}$ to $40 \mathrm{ft} 7 \mathrm{in}$. The tank builder was consulted for the safety of heightened level of water inside the tank, and confirmed the safety of the tank with the increased level of $7 \mathrm{in}$.

\section{Commissioning of System}

The tank was fully filled with city water. Chillers in CEP No. 2 completed charging the tank with chilled water during the weekend of 18 May 1996. The tank was fully charged by early morning 20 May (Monday). The temperature profile inside the tank ranged from $40^{\circ} \mathrm{F}$ at the bottom to $43^{\circ} \mathrm{F}$ at the top.

The ambient temperature in Columbia, SC on 20 May reached $99{ }^{\circ} \mathrm{F}$. By noon, all four chillers (1200 ton each) in the Energy Plant No. 2 were running to provide cooling for Fort J ackson. Starting from 1222 (20 May 1996), all four chillers were shut down: No. 1 chiller at 1222, No. 2 at 1252, No. 3 at 1307, and No. 4 at 1320. Note that the utility on-peak hours for Fort J ackson are between 1300 and 2100 . The chilled water in the tank met the entire cooling load during the peak hours. Chillers were brought back online starting at 1622 for No. 1, 1007 for No. 2, 1722 for No. 3, and 1807 for No. 4. This operation helped Fort J ackson keep its on-peak billing demand under 19,550 kW (Figure 8, "Hourly Load Profile of Fort J ackson, 20 May 1996"). On 20 May 1996, the electrical demand was peaking around 1100 at $23,000 \mathrm{~kW}$. Without the shutdown of the four chillers, the demand should have increased to over $23,000 \mathrm{~kW}$ in the early afternoon hours. Therefore, the minimum amount of peak shaving by the storage tank is $3450 \mathrm{~kW}$ (the difference between $23000 \mathrm{~kW}$ and $19550 \mathrm{~kW}$ ). Table 4 lists the thermal performance of the tank for the first complete cycle of charging and discharging. The table shows the temperature distribution inside the tank at a number of benchmark hours. Note that, for the first day of operation (20 May 1996), the tank was not fully discharged. Table 4 confirms the regenerating capability of the tank through the night of 20 May. By the morning of $21 \mathrm{May}$, the tank was fully recharged and ready to repeat the cooling cycle. 


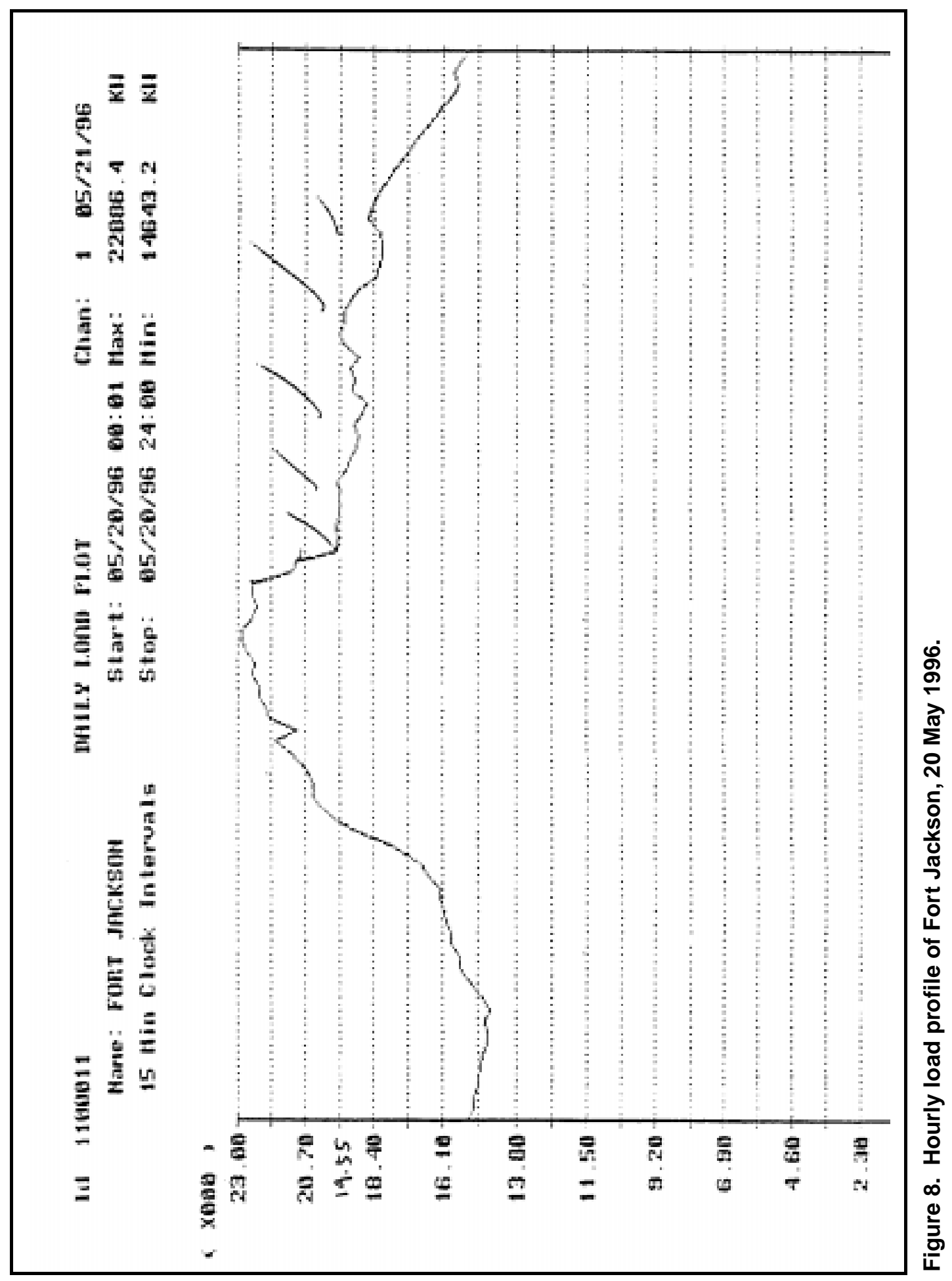


Table 4. Temperature distributions inside the tank.

\begin{tabular}{|c|c|c|c|}
\hline Sensor \# & $\begin{array}{l}\text { Date/Time } 20 \text { May } \\
1996(1710 \text { EDT })^{\circ} \mathrm{C} /{ }^{\circ} \mathrm{F}\end{array}$ & $\begin{array}{l}\text { Date/Time } 21 \text { May } \\
1996\left(0830 \text { EDT) }{ }^{\circ} \mathrm{C} /{ }^{\circ} \mathrm{F}\right.\end{array}$ & $\begin{array}{l}\text { Date/Time } 22 \text { May } \\
1996\left(0830 \text { EDT) }{ }^{\circ} \mathrm{C} /{ }^{\circ} \mathrm{F}\right.\end{array}$ \\
\hline 20 (top) & $13.8 / 56.9$ & $6.7 / 44.0$ & $7.3 / 45.2$ \\
\hline 19 & $13.5 / 56.3$ & $6.7 / 44.0$ & $7.2 / 44.9$ \\
\hline 18 & $13.2 / 55.8$ & $6.6 / 43.8$ & $7.0 / 44.6$ \\
\hline 17 & $12.8 / 55.0$ & $6.5 / 43.7$ & 7.044 .6 \\
\hline 16 & $11.8 / 53.3$ & $5.9 / 42.7$ & $6.4 / 43.6$ \\
\hline 15 & $11.1 / 51.9$ & $5.9 / 42.6$ & $6.1 / 42.9$ \\
\hline 14 & $10.6 / 51.1$ & $5.4 / 41.7$ & $5.8 / 42.5$ \\
\hline 13 & $10.2 / 50.4$ & $5.3 / 41.5$ & $5.8 / 42.4$ \\
\hline 12 & $9.9 / 49.9$ & $5.3 / 41.5$ & $5.7 / 42.3$ \\
\hline 11 & $5.5 / 41.9$ & $4.9 / 40.9$ & $5.4 / 41.7$ \\
\hline 10 & $4.8 / 40.7$ & $5.3 / 41.5$ & $5.7 / 42.3$ \\
\hline 9 & $4.3 / 39.8$ & $4.8 / 40.6$ & $5.2 / 41.3$ \\
\hline 8 & $4.2 / 39.6$ & $4.7 / 40.4$ & $4.9 / 40.9$ \\
\hline 7 & \multicolumn{3}{|c|}{ data missing } \\
\hline 6 & \multicolumn{3}{|c|}{ data missing } \\
\hline 5 & \multicolumn{3}{|c|}{ data missing } \\
\hline 4 & $4.8 / 40.7$ & $4.8 / 40.6$ & $5.5 / 41.9$ \\
\hline 3 & $4.9 / 40.9$ & $4.8 / 40.7$ & $5.7 / 42.2$ \\
\hline 2 & $4.9 / 40.9$ & $4.7 / 40.4$ & $5.5 / 41.9$ \\
\hline 1 (bottom) & \multicolumn{3}{|c|}{ data missing } \\
\hline
\end{tabular}




\section{System Operation and Performance}

\section{First Year Operation of System}

Since 20 May 1996, the tank operated as a part of the CEP No. 2 cooling system through the end of 1996 cooling season. During early May 1996, while repairing the diffuser, corrosion of aluminum parts installed inside the tank (i.e., support structure and pads for the lower diffuser segments) was observed. By late May 1996, the cooling load of Fort J ackson became a significant contribution to the peak electrical demand. Due to lack of time, it was decided to bring the tank on line to serve out the 1996 cooling season, after which the aluminum parts would be checked again to determine if further actions were needed at the end of the 1996 cooling season. Note that the corrosion of support members is not related to the thermal performance of the chilled water storage systems.

At the end of the 1996 cooling season, the tank was drained to inspect the integrity of the components inside the tank. On 23 J anuary 1997, the progress of corrosion on the support structure due to dissimilar metal contact inside the tank was examined by CERL and DPW engineers. The rate of progress was determined to be slow enough not to warrant immediate replacement of the supporting parts. A decision was made at the field inspection that the system would be operated without any replacement of components for the next 5 years. It was recommended that the tank be drained at the end of the 2001 cooling season and inspected for any needed remedial actions. To prevent further corrosion damage, the tank water was treated for corrosion inhibition at the beginning of 1997 cooling season. The treatment formula, recommended by CERL and the U.S. Army Corps of Engineers Installation Support Center (CEISC) were:

1. For aluminum: stainless steel and steel components is: Poly Silicate with $\mathrm{SiO}_{2}$ to $\mathrm{NaO}_{2}$ ratio equal to 3.22. The dosage is 200 ppm as $\mathrm{SiO}_{2}$ (Liquid).

2. For copper: Toly Triazole (TT) 50 percent sodium tolytriazole. The dosage is 50-100 ppm. 


\section{System Performance}

The electrical cost savings by the operation of the CWS cooling system for a year (J une 1996 to May 1997) was estimated based on the monthly electrical utility bills for Fort Jackson. Table 5 lists the monthly billing demands for Fort $J$ ackson during the past 4 years. Note that the annual peak demand for Fort J ackson has been reduced from 25,358 kW in 1995 to 23,424 kW in 1996 with operation of the CWS cooling system.

\section{Electrical Cost Savings in 1996-97}

Table 6 lists the monthly electrical energy consumption for Fort J ackson during the past 4 years. For each 12-month period (J une through May), the annual total energy consumption is $114.84 \mathrm{GwH}$ in 1994-5, $122.69 \mathrm{GwH}$ in 1995-6, and $120.2 \mathrm{GwH}$ in 1996-97. Note that the total energy consumption depends on the level of installation activities as well as fluctuating annual climate conditions. Quantitative determination of energy savings cannot be made from the monthly billing information.

Table 7 summarizes the monthly electrical bills for the past 4 years. A monthly bill has two components: one for the demand charge based on the billing demand (in $\mathrm{kW}$ ) each month (Table 5), and the other for the energy charge based on the monthly energy consumption (in kWH) (Table 6). A sum of the demand charge and the energy charge is the monthly electrical charge for Fort J ackson.

Table 8 summarizes impact of the CWS cooling system on the annual electrical utility cost for Fort J ackson. It shows changes in the electrical cost for each of 12-month (J une-May) period during the past 4 years.

Table 5. Monthly billing demand in $\mathrm{kW}$ for the past 4 years.

\begin{tabular}{|l|c|c|c|c|c|c|c|c|c|c|c|c|}
\hline Month & $\mathbf{1}$ & $\mathbf{2}$ & $\mathbf{3}$ & $\mathbf{4}$ & $\mathbf{5}$ & $\mathbf{6}$ & $\mathbf{7}$ & $\mathbf{8}$ & $\mathbf{9}$ & $\mathbf{1 0}$ & $\mathbf{1 1}$ & $\mathbf{1 2}$ \\
\hline 1994 & 17485 & 17485 & 17485 & 17485 & 19008 & 23155 & 22896 & 22810 & 22810 & 17485 & 18524 & 18524 \\
\hline 1995 & 18524 & 18524 & 18524 & 18524 & 20822 & 22896 & 24408 & 25358 & 22896 & 21470 & 20286 & 20286 \\
\hline 1996 & 20286 & 20286 & 20286 & 20286 & 21456 & 23136 & 23424 & 22752 & 21840 & 19872 & 17856 & 17856 \\
\hline 1997 & 17856 & 17856 & 17856 & 17856 & 19584 & 23328 & 24768 & 24432 & 22560 & 19920 & 18662 & \\
\hline
\end{tabular}

Table 6. Monthly billing demand in kW for the past 4 years.

\begin{tabular}{|l|c|c|c|c|c|c|c|c|c|c|c|c|}
\hline Month & $\mathbf{1}$ & $\mathbf{2}$ & $\mathbf{3}$ & $\mathbf{4}$ & $\mathbf{5}$ & $\mathbf{6}$ & $\mathbf{7}$ & $\mathbf{8}$ & $\mathbf{9}$ & $\mathbf{1 0}$ & $\mathbf{1 1}$ & $\mathbf{1 2}$ \\
\hline 1994 & 17485 & 17485 & 17485 & 17485 & 19008 & 23155 & 22896 & 22810 & 22810 & 17485 & 18524 & 18524 \\
\hline 1995 & 18524 & 18524 & 18524 & 18524 & 20822 & 22896 & 24408 & 25358 & 22896 & 21470 & 20286 & 20286 \\
\hline 1996 & 20286 & 20286 & 20286 & 20286 & 21456 & 23136 & 23424 & 22752 & 21840 & 19872 & 17856 & 17856 \\
\hline 1997 & 17856 & 17856 & 17856 & 17856 & 19584 & 23328 & 24768 & 24432 & 22560 & 19920 & 18662 & \\
\hline
\end{tabular}


Table 7. Monthly electrical cost (\$) for the past 4 years.

\begin{tabular}{|l|c|c|c|c|c|c|c|c|c|c|c|c|}
\hline Month & $\mathbf{1}$ & $\mathbf{2}$ & $\mathbf{3}$ & $\mathbf{4}$ & $\mathbf{5}$ & $\mathbf{6}$ & $\mathbf{7}$ & $\mathbf{8}$ & $\mathbf{9}$ & $\mathbf{1 0}$ & $\mathbf{1 1}$ & $\mathbf{1 2}$ \\
\hline 1994-KW & 116,015 & 115,805 & 116,015 & 121,097 & 143,260 & 324,638 & 321,015 & 319,811 & 319,811 & 128,919 & 145,558 & 145,558 \\
\hline $1994-\mathrm{KWH}$ & 136,472 & 158,824 & 144,501 & 157,874 & 188,738 & 291,494 & 315,226 & 320,185 & 268,695 & 156,891 & 174,155 & 156,697 \\
\hline 1994 sum & 252,487 & 274,629 & 260,596 & 278,971 & 331,998 & 616,132 & 636,241 & 639,997 & 588,507 & 285,810 & 319,713 & 302,255 \\
\hline & & & & & & & & & & & & \\
\hline $1995-\mathrm{KW}$ & 145,558 & 145,558 & 145,558 & 145,558 & 163,528 & 321,015 & 342,168 & 355,458 & 321,015 & 167,698 & 159,337 & 159,337 \\
\hline $1995-\mathrm{KWH}$ & 167,357 & 165,185 & 161,245 & 185,516 & 211,028 & 277,848 & 348,405 & 324,302 & 289,389 & 201,679 & 169,486 & 172,565 \\
\hline 1995 sum & 312,915 & 310,743 & 306,803 & 331,074 & 374,556 & 598,863 & 690,573 & 679,760 & 610,404 & 369,377 & 328,823 & 331,902 \\
\hline & & & & & & & & & & & & \\
\hline $1996-K W$ & 176,628 & 193,920 & 193,920 & 193,920 & 202,873 & 296,885 & 309,248 & 299,158 & 286,737 & 188,624 & 170,811 & 170,811 \\
\hline $1996-K W H$ & 159,192 & 171,092 & 166,915 & 177,570 & 210,167 & 275,235 & 321,835 & 298,411 & 218,449 & 241,277 & 169,937 & 182,338 \\
\hline 1996 sum & 335,820 & 365,012 & 360,835 & 371,490 & 413,040 & 572,120 & 631,083 & 597,569 & 505,186 & 429,901 & 340,748 & 353,149 \\
\hline & & & & & & & & & & & & \\
\hline $1997-K W$ & 172,953 & 172,953 & 172,953 & 172,953 & 189,107 & 312,323 & 327,022 & 320,113 & 303,166 & 190,721 & 163,378 & \\
\hline $1997-K W H$ & 164,450 & 174,543 & 171,965 & 163,332 & 174,907 & 278,116 & 324,871 & 304,166 & 296,461 & 208,501 & 169,988 & \\
\hline 1997 sum & 337,403 & 347,496 & 344,918 & 336,285 & 355,015 & 590,439 & 651,893 & 624,279 & 599,627 & 399,223 & 333,365 & \\
\hline
\end{tabular}

Table 8. Annual electrical utility cost for the past 4 years.

\begin{tabular}{|c|c|c|c|c|}
\hline 12-month (Jun-May) & Demand cost (\$) & Energy cost (\$) & Total cost (\$) & Demand/Total \\
\hline $1994-1995$ & $2,451,070$ & $2,573,674$ & $5,024,744$ & 0.4878 \\
\hline $1995-1996$ & $2,787,289$ & $2,668,610$ & $5,455,899$ & 0.5109 \\
\hline $1996-1997$ & $2,603,193$ & $2,556,679$ & $5,159,872$ & 0.5045 \\
\hline
\end{tabular}

For the first 12-month operation of the CWS cooling system, the system reduced the electrical cost for Fort J ackson from \$5.46M in 1995-96 to \$5.16M in 1996-97. During the 1996-97 period, a number of large buildings were added to Fort J ackson (9 buildings at a total floor area of 342,562 sq ft). Even with the increased electrical energy demand and consumption by these new buildings, the total electrical bill was reduced by $\$ 0.3 \mathrm{M}$ during the first 12-month operation of the CWS cooling system. Note that the annual electrical utility cost for Fort J ackson has been increasing during the past years, i.e., \$5.02M in 1994-95 and $\$ 5.46 \mathrm{M}$ in $1995-96$. Without the CWS cooling system, the trend will continue and the cost during 1996-97 would have been significantly higher than the cost during 1995-96. Therefore, the actual impact of the CWS cooling system on the cost savings will be significantly more than $\$ 0.3 \mathrm{M}$. The actual saving is estimated to be close to $\$ 0.43 \mathrm{M}$ based on the demand-shift capability of the system measured during the field test on 20 May 1996 (see "Economic Performance," p 29).

\section{Thermal Performance of the System}

The thermal efficiency of the storage tank depends on the creation and maintenance of a sharp thermocline inside the tank during operation. A snapshot of the thermocline characteristic was plotted with a three-channel temper- 
ature recorder (Figure 9). The three thermocouples were located vertically $15 \mathrm{ft}$ apart each inside the tank. The thermocline took $6 \mathrm{hr}$ (from 2320, 23 September 1997 to 0520, 24 September 1997) to travel $30 \mathrm{ft}$ vertically between the bottom and top sensors. That corresponds to a charging flow rate of $4688 \mathrm{gpm}$, which yields the charging inlet Reynolds Number of 760, based on the total diffuser length of $851 \mathrm{ft}$.

It is widely accepted that a charging Reynolds Number of less than 1000 establishes and maintains a good thermodine inside the tank (ASHRAE 1993). Figure 8 shows movement of a sharp thermocline inside the tank during the charging process through the night of 23-24 September 1997. The calculated depth of the thermocline ranges from $1 \mathrm{ft}$ at the bottom level, and $1.5 \mathrm{ft}$ at the mid-level and $2 \mathrm{ft}$ at the top level in the tank. Based on a conservative $2 \mathrm{ft}$ thickness of thermocline, a theoretical charge efficiency of the tank is calculated to be 95 percent (38/40). A sharper thermocline is expected to yield a better storage efficiency. The measurements of thermodine movement inside the tank (Figure 8) demonstrate the diffuser system is working properly. It is believed that a large number of similar systems are operating with the thermocline thickness in the range of up to $5 \mathrm{ft}$. For the Fort J ackson system, creation and maintenance of thermocline with a thickness less than $2 \mathrm{ft}$ shows an excellent thermal performance of the system.

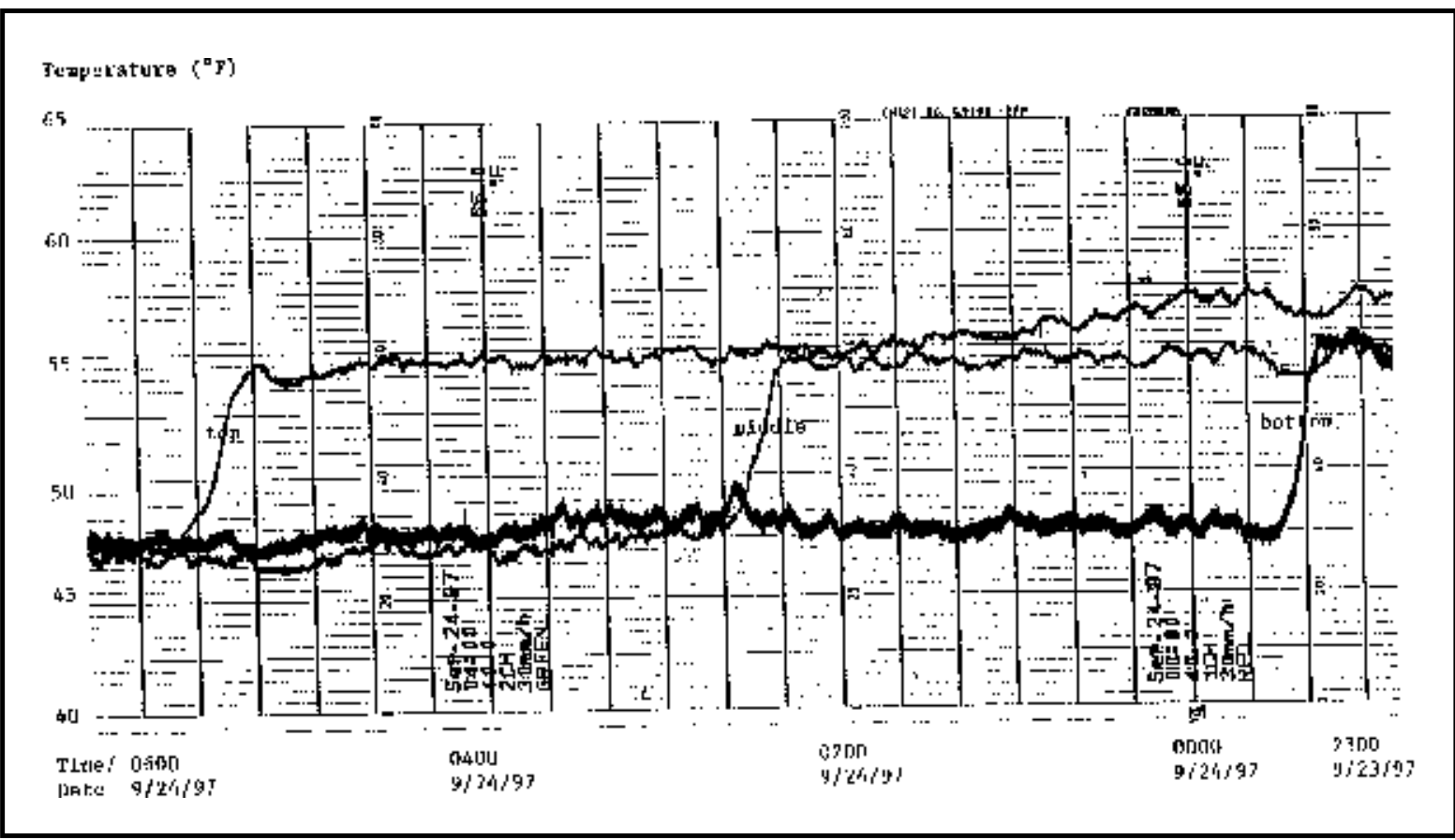

Figure 9. Profile of thermoclines within the tank. 


\section{Economic Performance}

The most significant benefit of the CWS cooling system is reduction in annual on-peak electrical demand of Fort J ackson. Due to the increasing level of activities at Fort J ackson, the annual peak demand has been growing $23,088 \mathrm{~kW}$ in 1989 to $25,358 \mathrm{~kW}$ in 1995 . Commissioning of the system at the beginning of 1996 cooling season reduced the annual peak demand to $23,424 \mathrm{~kW}$ in 1996 , thereby reducing the on-peak electrical demand by $1,934 \mathrm{~kW}$ compared to the year before. During the first 12-month (J une 1996-May 1887) operation of the system, the annual electrical utility cost for Fort J ackson has been reduced from $\$ 5.46 \mathrm{M}$ in $1995-6$ to $\$ 5.16 \mathrm{M}$ in $1996-7$ period. Note that during the 1996-7 period, a number of large buildings (of the total floor area 342,562 sq ft) were added to Fort J ackson inventory, which increased consumption of electricity. Therefore, actual savings during the first year of operation is a sum of $\$ 0.3 \mathrm{M}$ (savings reflected in the monthly bills), the increased electrical utility costs incurred by the new buildings brought on-line during the 1996-7 period, and yearly inflation of el ectrical utility cost.

A more realistic cost saving can be estimated from the commissioning data (Figure 8). By the time all four chillers in the Plant No. 2 were unloaded at 1320, 20 May 1996, the electrical demand registered at the F ort J ackson master meter had dropped from $23,000 \mathrm{~kW}$ at 1100 to $19,550 \mathrm{~kW}$ at 1320 . This shows the system capability in demand reduction by $3450 \mathrm{~kW}$. Each of the four chillers is rated at a 1200-ton capacity. For a total cooling tonnage of 4800 ton, the electrical demand of $3450 \mathrm{~kW}$ yields the chiller $\mathrm{kW} / \mathrm{ton}$ ratio of $0.72 \mathrm{~kW} / \mathrm{ton}$, which is quite reasonable for the centrifugal chillers. Based on the demand reduction of $3450 \mathrm{~kW}$ and the prevailing electrical rate structure of the South Carolina Electric and Gas Company, the annual cost savings is estimated to be $\$ 0.43 \mathrm{M} / \mathrm{yr}$. 


\section{Discussion}

\section{Project Execution}

An implementation of chilled water storage (CWS) to a central energy plant (CEP) requires a careful project schedule. An immediate concern is that a CEP typically serves a large number of cooling customers. Therefore its operation cannot be disrupted, especially during the cooling season. For the Fort J ackson project, the connection of the tank to the CEP No. 2 in the late spring of 1995 was seriously considered as an option. There were three options: (1) no cooling during the pipe connection work up to $1-1 / 2$ weeks, (2) a temporary cooling provision, or (3) delay of the project until the end of the cooling season. The first option was unacceptable to Fort J ackson. A quote for the temporary cooling during the outage of CEP No. 2 was received at a cost of $\$ 1.07 \mathrm{M}$, based on a 6 week period, including setup and teardown. Due to high cost of the option, the project was delayed until the end of 1995 cooling season. By the time when the Phase II was completed in March 1996, the 1-year warrantee on the tank construction had expired. When the breakage of the upper diffuser assembly was found out in March 1996 (See "System Commissioning," p 20), it was not clear when the failure had occurred, during the testing of the tank in early 1995 or during the commissioning test in March 1996. Completion of the project by a single source contractor would have avoided such confusion.

\section{Design and Construction}

The diffuser system inside the tank is the most critical element in successful performance of CWS cooling system. The octagonal diffuser system used in the Fort J ackson system (Figure 4) yielded excellent performance, as Figures 8 and 9 show. It was designed following the recommended design criteria of inlet Reynolds number less than 850, as suggested in the current industry design guide by the ASHRAE (1993). According to the ASHRAE guide, "F or tall tanks, $40 \mathrm{ft}(12 \mathrm{~m})$ deep or more, there is evidence that diffusers with inlet Reynolds number of 2,000 or more may provide acceptable stratification. For design purposes, a maximum of 2,000 for the Reynolds number should be used. In 
general, an upper limit of 850 is recommended, unless data are available for a specific tank to support proper stratification at higher Reynol ds numbers."

The strict requirement in the inlet Reynolds number criteria (less than 850) resulted in a rather complicated diffuser system (quadruple octagonal diffuser, Figure 4) for the Fort J ackson system.

For future applications, a double octagonal diffuser is recommended for a cylindrical tank. The double octagonal configuration will reduce the total length of the diffuser by a factor of two, thereby raising the inlet Reynolds number of a quadruple octagonal configuration by the same amount. The Reynolds number criteria may be increased up to 2000 for future tanks of height at least $40 \mathrm{ft}$ tall. Careful attention should be given to the number and size of slots for each diffuser segment. For the Fort J ackson system, the total cross-sectional area of slot outlet was designed to be the same as that of the 24-in. main transfer pipe. Operators at F ort J ackson expressed concerns for increased pressure drop across the tank loop. For future design, the total cross-sectional area of slot outlet will be designed to be a minimum of 150 percent of the cross-sectional area of the main transfer line. The increased outlet area will reduce the pressure drop across the tank and will reduce the outlet jet speed to achieve a better thermal stratification. Study of an optimal design Reynolds number is ongoing. Preliminary results will be available to the design community in early 1999 (ASHRAE 1998).

The Fort Jackson system experienced significant corrosion of aluminum components inside the tank. Careful attention should be given to the specifications of material inside the tank to avoid potential corrosion. Generally speaking, aluminum and copper components are not recommended inside the tank. A bypass line between the two main transfer lines to the tank should be installed right before entrance to the tank. The segment should be equipped with a manual butterfly valve to isolate the two main transfer lines during normal operation. The valve will remain open only during the filling and draining of the tank to eliminate potential air pockets inside the diffuser system. The size of the bypass line could be half of the main transfer line, which showed itself to work well for the Fort J ackson system. To avoid potential water hammer damage, all the valve actuators must be slow acting. Use of an adjustable speed drive for main circulation pumps is a good approach to avoid fluid transient problems and to provide optimal control for cooling service. Close inspection of construction workmanship to match the design specifications is important for the project's success. Special attention should be given to the 
construction and installation of diffuser segments and leveled installation of upper diffuser assembly.

\section{Commissioning and Operation}

The commissioning process should begin with a final inspection of workmanship and acceptance testing of the system. The most critical phase is the initial filling of the tank with city water. An accurate reading of flowmeter in the main transfer line is a critical item to be verified. The contractor should have developed a detailed procedure for filling the tank to avoid damage to the structure inside the tank. Tank integrity should be tested with a fully charged tank. The operation of a level sensor should be checked when the tank water level reaches near the design height. A proper operation of the level sensor is critical to avoid potential exposure of upper diffuser slots to the atmosphere during an emergency loss of water from the system. Note that the tank is a part of the entire cooling loop; any loss of water (at the building or along the distribution line) will result in a lowering of the tank level unless makeup water is supplied on time. A dial pressure gauge located at the bottom of tank is a useful guide to check the filling rate into the tank.

Water should be treated as local requirements specify. Note again that the water in the tank is circulating along the entire cooling loop, including distribution systems and buildings. Treatment of water for required protection of coils and pipes should be equally applied to the water filled into the tank.

When the tank is completely filled with city water, the temperature sensors (installed at 2-ft intervals from top to bottom) should provide uniform temperature distribution vertically. It is critical to verify accurate reading of temperature sensors and flow meters installed in the main transfer lines for acceptance testing and for future successful operation of tank. Together, flow rate inside the main transfer line and the differential temperature between the two main transfer lines, determine the amount of cooling stored into the tank and cooling delivered by the tank. Once again, this emphasizes the importance of a flow meter in the main transfer line and temperature sensors across the two main transfer lines. A project implementation guide by ASHRAE (1996) details further recommendations for acceptance and commissioning testing. 


\section{Conclusion}

Fort J ackson, USACE Savannah District, and CERL designed and built a large capacity $(2.25 \mathrm{M}$ gal) chilled water storage cooling system for the Central Plant No. 2 at Fort J ackson, which serves more than half of Fort J ackson's cooling load. The system completed a successful operation for 2 years, resulting in an annual electrical utility cost savings of $\$ 0.43 \mathrm{M}$ for Fort J ackson. The system performed successfully, exceeding the original design goal of shifting $3000 \mathrm{~kW}$ of on-peak demand to off-peak periods. Results of commissioning testing done on 20 May 1996 showed that the system reduced Fort J ackson's post-wide electrical demand by $3450 \mathrm{~kW}$ when the four chillers in CEP No. 2 were unloaded with cooling provided by the storage tank. A review of the monthly electrical utility bills showed a significant reduction of Fort J ackson's growing annual electrical on-peak demand.

Valuable lessons were learned during the system's design, construction, and operation, specifically regarding:

1. Tank sizing ( $p$ 9)

2. Tank configuration ( $p$ 10)

3. Internal diffuser design ( $p$ 11)

4. Corrosion prevention ( $p 24)$.

Two more chilled water storage cool ing systems are currently under construction by the Savannah District: one for the CEP No. 1 at Fort Gordon, GA, and the other for CEP No. 1 at Fort J ackson, SC. Lessons from the Fort J ackson CEP No. 2 project will serve a useful guide for successful construction and operation of these systems. 


\section{References}

Akbari, H., and S. Konopacki, End-use Energy Characterization and Conservation Potentials at DoD Facilities: An Analysis of Electricity Use at Fort Hood, Texas, LBL-36974 UC-000 (Lawrence Berkeley Laboratory, May 1995).

American Society of Heating, Refrigerating, and Air Conditioning Engineers (ASHRAE), Design Guidefor Cool Thermal Storage(1993).

ASHRAE, Guide to Successful Implementation of Cool Storage Projects, ASHRAE 850-RP (May 1996.).

ASHRAE, Parametric Dependence of the Performance of Stratification in Thermal Storage Tanks, Research Project 992-RP (project duration April 1997 to October 1998).

Burch, S., "Chilled Water Storage Tank Design, Fort J ackson, SC," Conference Proceedings for the 1995 USACE E\&M Training Conference, 5-9J une 1995 (St. Louis, MO, 1995), pp 252-258.

Headquarters, U.S. Army Corps of Engineers (HQUSACE), Thermal Energy Storage Units: I ce-onCoil, CEGS-15848 (HQUSACE, Washington, DC, October 1996).

Memorandum of Understanding (MOU) between Fort J ackson and the South Carolina Electric and Gas Company (15 May 1995).

Sohn, C.W., and G.L. Cler, Market Potential of Storage Cooling Systems in the Army, Technical Report (TR) E-89/13/ADA213977 (U.S. Army Construction Engineering Research Laboratories [CERL], September 1989).

Sohn, C.W., Feasibility Study of a Storage Cooling System for Central Energy Plant \#2 at Fort J ackson, SC, Letter Report to DPW Fort J ackson (CERL, J une 1990).

Sohn, C.W., J . Fuchs, and M. Gruber, Lessons from a Chilled Water Storage Cooling System at F ort J ackson, SC, paper presented at the 1998 USACE E\&M Training Conference (Kansas City, KS, 1-4 J une 1998).

Sohn, C.W., Lessons from Field Demonstration and Testing of Storage Cooling Systems, Technical Note (TN) 5-670-1 (U.S. Army Engineering and Housing Support Center [EHSC], Fort Belvoir, VA [currently the U.S. Army Corps of Engineers Installation Support Center [CEISC], Alexandria, VA], April 1992). 
Chief of Engineers

ATTN: CEHEC-IM-LH (2)

ATTN: CEHEC-IM-LP (2)

ATTN: CECG

ATTN: CECC-P

ATTN: CECC-R

ATTN: CECW

ATTN: CECW-O

ATTN: CECW-P

ATTN: CECW-PR

ATTN: CEMP

ATTN: CEMP-E

ATTN: CEMP-C

ATTN: CEMP-M

ATTN: CEMP-R

ATTN: CERD-C

ATTN: CERD-ZA

ATTN: CERD-L

ATTN: CERD-M (2)

ASC(IM) 22060

ATTN: DAIM-FDP

CEISC 22310-3862

ATTN: CEISC-E

ATTN: CEISC-FT

ATTN: CEISC-ZC

US Army Engr District ATTN: Library $(40)$

US Army Engineering and Support Center ATTN: CEHND 35807-4301

USA TACOM 48397-5000 ATTN: AMSTA-XE

Defense Distribution Region East ATTN: ASCE-WI 17070-5001

Defense Distribution Region West ATTN: ASCW-WG 95296-0100

HQ XVIII Airborne Corps 28307 ATTN: AFZA-DPW-EE

$4^{\text {th }}$ Infantry Div (MECH) $80913-5000$ ATTN: AFZC-FE

US Army Materiel Command (AMC) Alexandria, VA 22333-0001

ATTN: AMCEN-F

ATTN: AMXEN-C 61299-7190

Installations: (20)

FORSCOM

Forts Gillem \& McPherson

30330

ATTN: FCEN

Installations: (20)

$6^{\text {th }}$ Infantry Division (Light) ATTN: APRVR-DE 99505 ATTN: APRVR-WF-DE 99703

TRADOC

Fort Jackson 29207

ATTN: ATZJ-PWO-E

Fort Monroe 23651

ATTN: ATBO-G

Installations: (19)

\section{USACERL DISTRIBUTION}

Fort Belvoir 22060

ATTN: CETEC-IM-T

ATTN: CETEC-ES 22315-3803

ATTN: Water Resources Support Ctr

USA Natick RD\&E Center 01760

ATTN: STRNC-DT

ATTN: AMSSC-S-IMI

CEWES 39180

ATTN: Library

CECRL 03755

ATTN: Library

USA AMCOM

ATTN: Facilities Engr 21719

ATTN: AMSMC-EH 61299

ATTN: Facilities Engr (3) 85613

USAARMC 40121

ATTN: ATZIC-EHA

Military Traffic Mgmt Command ATTN: MT-LOF 22041-5000 ATTN: MTE-SU-FE 28461

Fort Leonard Wood 65473 ATTN: ATSE-DAC-LB (3) ATTN: ATZT

ATTN: ATSE-CFLO

ATTN: ATSE-DAC-FL

ATTN: Australian Liaison Office

Military Dist of WASH Fort McNair

ATTN: ANEN-IS 20319

USA Engr Activity, Capital Area ATTN: Library 22211

US Army ARDEC 07806-5000 ATTN: AMSTA-AR-IMC

Linda Hall Library ATTN: Acquisitions 10017

Defense Logistics Agency ATTN: MMDIS 22060-6221

National Guard Bureau 20310 ATTN: NGB-ARI

US Military Academy 10996 ATTN: MAEN-A

ATTN: Facilities Enginee ATTN: Geography \& Envr Engrg

Naval Facilities Engr Command ATTN: Facilities Engr Command (8)

ATTN: Engrg Field Divisions (11)

ATTN: Public Works Center (8)

ATTN: Naval Constr Battalion Ctr 93043

ATTN: Naval Facil. Engr Service Ctr 93043-4328

$416^{\text {th }}$ Engineer Command 60623 ATTN: Gibson USAR Ctr

US Army MEDCOM ATTN: MCFA 78234-6000

Navy Env Health Ctr 23513-2617
Air Force Medical Logistics Ofc 21702-5006

Fort Sam Houston 78234-5000 ATTN: MCFA-PW

Fitzsimon's Army Medical Ctr ATTN: MCHG-PW

Walter Reed Army Medical Ctr 20007-5001

ATTN: MCHL-PW

Tyndall AFB 32403 ATTN: HQAFCESA/CES ATTN: Engrg \& Srvc Lab

USA TSARCOM 63120 ATTN: STSAS-F

American Public Works Assoc. 64104-1806

US Army CHPPM ATTN: MCHB-DE 21010

US Gov't Printing Office 20401 ATTN: Rec Sec/Deposit Sec (2)

Nat'l Institute of Standards \& Tech ATTN: Library 20899

Defense General Supply Center ATTN: DGSC-WI 23297-5000

Defense Construction Supply Center ATTN: DCSC-WI 43216-5000

Defense Tech Info Center 220606218

ATTN: DTIC-O (2)

SERDP Support Office 22102

SERDP Office 22203 